\title{
TOPICAL ISSUES OF ECONOMIC CRIME INVESTIGATION: EUROPEAN VECTOR
}

\author{
Olena Volobuieva ${ }^{1}$, Tetiana Shevchenko ${ }^{2}$
}

\begin{abstract}
The aim of the article is to analyse topical issues arising during the investigation of economic crimes in Ukraine and abroad, as well as to develop concrete suggestions to optimize the investigation of such crimes. The subject of the study is the topical issues of the investigation of economic crimes: the European vector. Methodology. The analysis of legal regulations of Ukraine and scientific literature enabled to study the current state of combating organized groups committing economic crimes and to determine the strategic priorities and objectives of counteraction to this socio-negative phenomenon in Ukraine, as well as dialectical method, scientific abstraction, methods of system analysis, were used. The results of the study revealed that the authors proposed the perspective concerning a strategy, ways, and mechanisms for overcoming economic crime in Ukraine through the introduction of advanced European experience. Practical implications. The study and adoption of positive foreign experience in countering organized crime in the economic sectors, individual elements and introducing them into the law enforcement bodies' practice in Ukraine would enable to improve performance during the investigation of economic crimes. Relevance/originality. A comparative analysis of the investigation of economic crimes in foreign countries enabled to develop the most promising areas to improve domestic legislation in this sphere.
\end{abstract}

Key words: economy, economic crime, investigation, Euro-integration, strategy.

JEL Classification: K13, F36, C41

\section{Introduction}

The relevance of the study of economic crime features and the analysis of their commitment is exacerbated by the economic instability in the state and the struggle for economic power. Any crime is always predetermined by a certain factor or condition. The variety of ways to commit crimes in the economic sectors, criminals' use of various technologies and operations, and other factors contributing to the commission of unlawful acts in the economic sectors lead to significant difficulties in their investigation. In the context of this issue, it should be noted that the features of the crime are characterized by different aspects and phenomena that they reflect, therefore, their identification and specification is a priority task in the detection and investigation of economic crimes. With the advent of new economic conditions, new ways of economic criminal act mechanisms have emerged (Skakun, 2018).

To counteract effectively the threats to the state financial security, in particular, corruption and depletion of the state financial resources require continuous operation of the system of timely identifying and addressing systemic risks in public finance, preventing their occurrence in the future (Ukrainskyi OLAF).

At the present stage of the formation of Ukraine as a European state, a complex of strategic measures aimed at the development of the economy in the conditions of European integration is in progress (Yunin, Sevruk, Pavlenko, 2018). XXI century is an era of globalization, which is realized in the objective reality as a multifactorial and poly-functional phenomenon with both positive and negative impacts on the development of society. Therefore, modern political and legal literature fairly argues that globalization is "not absolute evil and not absolute good” (Ebzeev, Aibazov, Krasnoriadtsev, 2006; Tatsii, 2008; Sevruk, 2018). Therefore, nowadays Ukraine has declared Euro-integration as a key priority of economic policy. The need to develop the integration strategy of Ukraine has been caused by the strive of our state to meet the requirements of the modern world economic system; it is the way of modernizing the economy, overcoming technological backwardness, involving foreign investments and the latest technologies, creating new jobs, increasing the competitiveness of the domestic commodity producer, and entering the world markets.

Therefore, consideration of this issue reveals that in the case of detecting unlawful acts of economic crime, representatives of law enforcement bodies encounter some difficulties. Investigation materials may be quite large, while they may not contain the necessary facts. In addition, the analysis of such materials requires

Corresponding author:

${ }^{1}$ Donetsk Law Institute of the Ministry of Internal Affairs of Ukraine, Ukraine.

${ }^{2}$ National Academy of Internal Affairs of Ukraine, Ukraine. 
specific knowledge. Evidently, to concentrate efforts to complete the investigation of a major economic crime is hard work, because current cases also require engaging a police officer or an investigator (Kravchuk, 2009).

Over recent years, in Ukraine, under economic transformation, the most vulnerable economic crimes are detected, such as non-disclosure of the revenue position and, consequently, non-payment of taxes; fraud with financial resources, determined by the plans of private banks to obtain mega-profits by manipulating imperfect legal provisions of the state; in the foreign exchange market, concealing and reducing the sale of foreign currency in order to increase sharply the foreign currency rate, but consequences are evident; artificial increase and maintenance of high prices for goods, medicines and services and poor quality production, harmful to health of consumers, repeatedly reported in the media (Mochkosh, 2012).

Therefore, it should be noted that this state of affairs is related to crime adjustment to the transformations of the socio-economic structure of society and dynamic reactions to social and legal control in order to avoid it (Sevruk, 2017).

A significant contribution to the study of economic crimes investigation has been made by foreign and domestic scientists such as L. H. Androsovich, O. M. Dzhuzha, S. B. Yehorycheva, O. H. Kalman, S. Y. Kravchuk, I. E. Lapinskyi, Ya. V. Mochkosh, V. I. Muntiian, V. Ortynskyi, S. V. Onishchenko, Yu. Yu. Orlov, S. O. Pavlenko, O. V. Pchelina, V. V. Ruden, V. H. Sevruk, T. O. Skakun, V. Ya. Tatsii, D. M. Kharko, O. Shostko.

The aim of the article is to analyse topical issues arising during the investigation of economic crimes in Ukraine and abroad, as well as to develop concrete proposals to optimize the investigation of such crimes.

\section{Presentation of the main material}

Crime in economic relations continues to have a negative impact on the development of the state. Modern economic crimes are characterized by complex and sophisticated ways and methods of their commission; therefore, one of the main problems is the increase in the professionalism and authority of investigating units. Its solution is to provide investigative units with highly skilled personnel who shall meet current requirements and be able to investigate crimes professionally to protect the economy from criminal encroachments (Ortynskyi, 2017).

Ukraine has declared its willingness to enter the European commonwealth of developed democracies that have high standards of safety, well-being and living of people, as well as the priority of human rights, the rule of law, and ensuring the inevitability of punishment for those who committed a crime. Strengthening of democratic institutions is impossible without reducing the negative effects of corruption and organized crime, which in our country remain one of the greatest threats of these days (Yevropeyskyi dosvid zapobihannia orhanizovanii zlochynnosti: teoretychni pytannia).

Nowadays, the state of affairs in the Ukrainian economy, transformations and processes that have taken place in the past, and especially over recent years, convincingly testify that the solution of socio-economic development problems has become strategic, global, and one of the most important in the state. The overcoming of crisis phenomena, struggle with the consequences of the global financial crisis, transition to sustainable economic growth require further elaboration of the mechanisms of the economic regulation both at the state and at the regional level (Ruden, 2014).

Therefore, the current system of measures of countering organized crime in the financial system is based on the basic principles, such as:

- the lower limit for a financial transaction shall be imposed, above which all transactions of a certain type are subject to registration by the institutions and persons specified by the law for the purpose of possible further verification - as a rule, this is from 10 thousand US dollars;

- the list of features shall be developed and introduced to determine whether a financial transaction can be classified as money laundering or terrorist financing;

- the designated entities, through which or with which help financial transactions are carried out, shall be responsible for informing law enforcement or supervisory bodies regarding suspicious transactions; - the governments of the countries provide one of the executive authorities with the right to coordinate the activities of all law enforcement and supervisory bodies in combating the legalization of proceeds and terrorist financing, which acquires the status of the financial intelligence unit (Yehorycheva, 2014).

Scientific interest in the problem of economic crime and the complexity of overcoming it is due to a differentiated approach to the definition of economic crimes in the domestic literature. Variety of these phenomenon interpretations is found in the works of many scholars, defining, for example, "crimes in the economic sectors", "economic crimes", "shadow economy", "criminal economy", "economic crime" and others. These concepts are often considered equivalent, but there are attempts to prove the different nature of these phenomena. According to O. Yakovliev, an economic crime as a property and mercenary crime, as well as a crime in the economic sphere, the author argues that economic crime is characterized by a combination of mercenary offences against property, the order of management of the national economy, committed by persons who are on certain social positions in the economic structure. According to S. Kravchuk, all these concepts have a different spectrum of committing unlawful acts. For example, crimes in the economic 
sectors, according to the author, are mainly economic crimes committed in various spheres; economic crime involves committing crimes in the economic activity, including using the official position. S. Kravchuk classifies acts related to the material damage or profits as crimes of an economic nature (Kravchuk, 2009).

According to O. H. Kalman, the main features of crime in the economic sectors are: 1) they are committed in the legal and illegal economic activity; 2) the subjects of these crimes can be entrepreneurs and other persons, who facilitate economic activity implementation; 3) they cause economic, political, moral harm to society and the state; 4) they are aimed at obtaining economic benefits; 5) they are committed only intentionally; 6) they can be committed by various means provided by the current criminal legislation (Kalman, 2004).

$\mathrm{S}$. Kravchuk argues that economic crime is crimes committed in the economic sectors with the use of legitimate technical and accounting, financial and accounting, supervisory and managerial rights and powers. The scientist identifies eight essential features inherent in economic crime: a continuing nature; high latency; set up by the criminal acts of business entities; offence against the order of economic management; committed by individuals (because, according to criminal law, the subject of a crime can be only an individual); a close connection with organized crime, corruption and shadow economic activity; formation of semi-criminal mentality among citizens of the state; significant damage to the state, society or individual citizens (Kravchuk, 2009).

Crimes in economic sectors are mostly latent requiring the use of operational unit capabilities such as their forces, tools, and methods (Orlov, 2006).

In his work, "Criminological problems in determining the concept and features of modern economic crime as a factor of shadow economy of Ukraine," D. M. Kharko highlights the features of economic crime, such as: it is a type of crime, which is applied mainly in mass, correspondingly, causing massive harm; it covers various abuse of economic power; it is committed in the course of the professional activity of the manager's authority; it has a plurality of episodes of committing a crime; it is committed both by individuals and legal entities; it is a more complex socio-economic phenomenon than traditional crime; it is of a latent nature; it causes significant economic damage to the interests of the state (Kharko).

According to S. S. Cherniavskyi, measures for the investigation of economic crime should be aimed at: using operational unit data, the study of review acts, audits, etc., obtaining information from law enforcement and supervisory bodies (departments of the State Fiscal Service of Ukraine, the State Financial Inspection of Ukraine, the National Bank of Ukraine, the State Customs Service of Ukraine, etc.) (Kovalenko, Moisieiev, Tatsii, Shemshuchenko, 2010).
The special danger of such acts is due to the possibility to use the technology for their implementation in any branch of public economy or business. Moreover, such acts are not only a source of accumulation of capital of illegal origin but also a means of their laundering. Such unlawful economic acts include:

- formation and issue of false money in non-cash payment circulation, which leads to illegal emission; - forgery, use and transfer to the circulation of a fraudulent document by a public official both in own interests and in the interests of third parties;

- using funds obtained illegally in the official business activity;

- fraudulent entrepreneurship;

- wilful violation of the proper accounting;

- fraudulent bankruptcy of a business entity;

- using budget funds in the interests of individual private entities or entrepreneurs;

- theft of funds through breaking into electronic banking networks;

- economic espionage (Kravchuk, 2009).

In the course of the study, the questioning of the bodies of the National Police of Ukraine established that in 91\% of cases, our state should consider foreign experience in countering organized crime in the economic sectors.

It should be noted that primary, one of the most effective instruments of anti-shadowing in many countries of the world is the systems and mechanisms for financial control over illegal proceeds. For example: a) in Italy, a government decree bans cash payments for large sums; b) in Germany, settlements with nonresidents requires declaration; c) in Japan, obligatory financial monitoring exists (financial institutions are obliged to report on major financial transactions to authorized public authorities). Meanwhile, in Germany, not only banks and financial institutions but also lawyers, auditors should report suspicious transactions to financial monitoring bodies in Germany (Muntiian, 1999; Europe: Hidden economy, 2011; European Security, 1995; Onyshchenko, Lapinskyi, 2013).

Therefore, V.H. Sevruk argues that the system should have interstate status and concentrate information of all law enforcement agencies and special international law enforcement structures (Interpol, Europol, BCFOC, Eurojust, FATF, Egmont Group, MONEYVAL, the Eurasian Group on Combating Money Laundering and Financing of Terrorism (EAG), the Basel Committee on Banking Supervision, the Wolfsberg Group, the International Monetary Fund, the World Bank, the European Bank for Reconstruction and Development). Such a system enables to overcome this phenomenon on a global scale, and for those who counter organized crime in the financial system, creates preconditions for international cooperation on countering the problem in general (Sevruk, 2017).

In recent years, control over organized crime in economic activity has become part of international 
policy: according to the European Security Strategy (adopted on December 12, 2003), the organized crime, along with terrorism and regional conflicts, is considered as one of the main threats to European countries; the EU member countries, in 2004, signed the Pre-Accession Pact on the development of joint measures for organized crime, and the European Commission has proposed the creation of the European forum for the prevention of organized crime in the economy and finances; in 2004, the Council of Europe approved the Hague Program for the establishment of the Area of Freedom, Security and Justice for 2005-2010 to shift from a reactive approach to a proactive (preventive) one to combat organized crime; at the Council of Europe meeting of June 12-13, 2007, the report "Assessment of organized crime threats" was heard and conclusions were made on the need for joint measures to combat organized crime in the $\mathrm{EU}$, in accordance with the Convention of 12 July 2000 on mutual legal assistance in civil and criminal matters (Shostko, 2008).

Criminalistics literature identifies a number of unlawful acts that constitute economic crimes. These include: violation of anti-dumping legislation (indicating offenses related to violation of the rules of free competition); fraud, production of bad products (offenses that violate consumers' rights); fraud with securities, accounting documentation, fraudulent bankruptcy, use of fraudulent bank documents (crimes based on abuse of investments, deposit capital, which cause significant losses to shareholders, creditors, etc.) (Kharko). Economic crimes have an extremely complicated mechanism of implementation, and therefore, a complicated mechanism for their detection and investigation. The mechanism of crime is the system of interaction of all crime participants between themselves and the environment, which leads to the formation of forensically relevant information about the crime, its participants, and results. The mechanism of a crime contains information on how this or that crime has been committed in the economic sectors. The specificity of committing an economic crime is the subject matter of such an illegal act, that is, property as a capital, therefore, an increased organization and use of specific manners occur. Another feature of committing economic crimes is criminal act commitment under the guise of various types of civil law agreements, therefore, they look like quite legitimate economic and financial transactions (Pchelina, 2009).

The leaders of organized crime groups focus on the search and establishment of corruption relations with public officials, responsible for law enforcement and regulatory activities in the economic sectors, judges, heads of local authorities and other officials whose competence includes the adoption of important decision for organized criminal groups. This contributes to the increase in the number of corrupt officials who hold responsible positions. It should also be considered that corruption is characterized by a high level of latency (Dzhuzha, 2007; Pavlenko, 2013).

It should be emphasized that in recent years, the development of the Ukrainian economy demonstrates unsustainable dynamics, which confirms the different adaptations of its branches to the challenges of our time, and results in lower investment and innovation activity and competitiveness. In addition, Ukraine steadily holds "honourable" places among the most corrupted countries (Kondratenko, 2018).

It should be noted that Ukraine has developed a strategy for introducing European standards of living in Ukraine and entering leading positions in the world. For this, the steps will be taken in such vectors:

$\checkmark$ the vector of development is the provision of sustainable development of the state, implementation of structural reforms and, consequently, improvement of living standards. Ukraine should become a state with a strong economy with advanced innovations. To do this, primary, it is necessary to restore macroeconomic stability, to ensure sustainable growth of the economy in an environmentally sound way, to create favourable conditions for conducting the economic activity and a transparent tax system;

$\checkmark$ the vector of security is the provision of security guarantees for the state, businesses and citizens, the protection of investments and private property. Ukraine shall become a state capable of protecting its borders and ensuring peace not only in its territory but also in the European region. The defining basis for security should also be the provision of fair and impartial justice, urgent lustration of authorities at all levels, and ensuring the implementation of effective anti-corruption mechanisms.

Nowadays, Europol coordinates the work of the police services of all 28 European Union member states. In contrast to national police forces, Europol does not have its own investigative authorities. Europol works closely with law enforcement agencies in $28 \mathrm{EU}$ member states and other partner states and non-EU countries such as Australia, Canada, the United States and Norway (Yevropol). Furthermore, Europol has relationships with the EU member states and organizations that interact with Europol according to cooperation agreements: Albania, Australia, Canada, Colombia, Iceland, Norway, Switzerland, Interpol, and US law enforcement agencies: the Bureau of Alcohol, Tobacco, Firearms and Explosives (ATF), the Drug Enforcement Administration (DEA), the Secret Service (USSS); the Federal Bureau of Investigation (FBI) the Immigration and Customs Enforcement (ICE) and the Internal Revenue Service (IRS). This network has secured communication channels provided by Europol. In addition, Europol 
has two liaison officers deployed to Washington DC (USA) and the Interpol Headquarters in Lyon, France (Yevropol).

Currently, a number of issues should be considered in the practice of this area. Therefore, taking into account the survey results, it has been determined that scientific development of countering organized crime in the financial sphere needs to be improved through the definition of the concept-categorical apparatus of organized crime in the financial sphere $(72 \%)$, the study of organized crime in the financial sphere as a criminological phenomenon (68\%), others (63\%). In this context, for Ukraine, precisely the study of the foreign experience of foreign countries, which have succeeded in this area, is considered as a determining factor by $87 \%$ of respondents (Androsovych, 2018). Therefore, S. O. Pavlenko highlights that a society brought up in a low morale environment cannot effectively counteract organized crime in the financial system. For that reason, priority measures of state policy should be moral upbringing of the personality (Pavlenko, 2015).

Indubitably, under the current economic situation in Ukraine, not all the positive foreign experience in countering organized crime in the financial system can be introduced, but studying its individual elements and implementing them into the practice of Ukrainian law enforcement bodies will improve performance in countering organized crime in the economic sectors.

\section{Conclusion}

Therefore, the question of the need to create an effective system of countering organized crime in the economic sectors in Ukraine arises. For that reason, the use of foreign experience of public mechanisms for preventing and countering organized crime in the economic sectors enables to formulate a set of effective national levers of public regulatory influence in counteracting this type of crime. The specificity of economic crimes prevents law enforcement bodies from responding promptly to their commission. Certainly, the state reacts to these crimes and tries to prevent them. For example, the National AntiCorruption Bureau of Ukraine is created, the Department for investigation of cases of particular importance in the economic sectors functions, Public Procurement Site Prozorro is created, and many other steps in this area are taken. However, the practice shows that all actions of the authorities to prevent economic crimes are accompanied by the emergence of more innovative mechanisms for committing economic crimes. Therefore, this topic is extremely important and it will be relevant for research for a long time (Skakun, 2018).

The issue of organized crime in the economic sectors has become international recently. Moreover, the world community recognizes that organized crime in the financial system has become a global threat to economic security; consequently, states are required to adopt coordinated measures to combat this socially dangerous activity, both at the national and international levels.

\section{References:}

Skakun, T. O. (2018). Ekonomichni zlochyny: sutnisni oznaky ta kryminalistychnyi analiz ikh vchynennia [Economic crimes: intrinsic features and criminalistics analysis of their commission]. Efektyvna ekonomika, 3. Retrieved from: http://www.economy.nayka.com.ua/pdf/3_2018/155.pdf (in Ukrainian)

Ukrainskyi OLAF. Yakym buty Natsionalnomu biuro finansovoi bezpeky? [Ukrainian OLAF. What the National Bureau of Financial Security should be?]. Retrieved from: http://www.interbuh.com.ua/ua/documents/ onenews/121151 (in Ukrainian)

Yunin, O., Sevruk, V., Pavlenko, S. (2018). Priorities of economic development of Ukraine in the context of European integration. Baltic Journal of Economic Studies, 4(3), 358-365. doi: 10.30525/2256-0742/2018-4-3-358-365

Ebzeev, B. S., Aibazov, R. U., Krasnoriadtsev, S. L. (2006). Globalizatsiia i gosudarstvennoe yedinstvo Rossii [Globalization and state unity of Russia]. Moskva. (in Russian)

Tatsii, V. Ya. (2008). Borotba zi zlochynnistiu na mezhi XXI stolittia - problema sohodennia [Combating crime at the turn of the 21st century: Problem of the present]. Problemy zakonnosti, 99, 3-18. (in Ukrainian)

Sevruk, V. H. (2018). Poniattia ta sutnist etnichnoi zlochynnosti [The concept and essence of ethnic crime]. Forum prava, 4, 64-94. Retrieved from: http://nbuv.gov.ua/UJRN/FP_index.htm_2018_4_8.pdf (in Ukrainian) Kravchuk, S. Y. (2009). Ekonomichna zlochynnist v Ukraini. Kurs lektsii. Navchalnyi posibnyk [Economic crime in Ukraine. Course of lectures. Textbook]. K.: Kondor. (in Ukrainian)

Mochkosh, Ya. V. (2012). Problemy borotby z ekonomichnoiu zlochynnistiu [Problems of combating economic crime]. Chasopys Kyyiuskoho universytetu prava, 2, 299-304. Retrieved from: http://nbuv.gov.ua/UJRN/ Chkup_2012_2_72(in Ukrainian)

Sevruk, V. H. (2017). Aspekty protydii zlochynam, shcho vchyniaiutsia v ekonomichnii sferi orhanizovanymy hrupamy i zlochynnymy orhanizatsiiamy, sformovanymy na etnichnii osnovi [Aspects of counteraction to crimes committed in economic sectors by organized groups and criminal organizations formed on an ethnic basis]. Proceedings from Interdepartmental scientific and practical conference on shadow economy: world trends and Ukrainian realities. (Kyiv, June 23, 2017). V. V. Cherniei, S. S. Cherniavskyi, V. I. Shakun, etc. (Eds.). Kyiv: National Academy of Internal Affairs. (in Ukrainian) 
Ortynskyi, V. (2017). Osoblyvosti planuvannia rozsliduvannia zlochyniv u sferi ekonomiky [Specificities of planning for the investigation of economic crimes]. Visnyk Natsionalnoho universytetu "Lvivska politekhnika". Yurydychni nauky, 861, 4-10. (in Ukrainian)

Yevropeyskyi dosvid zapobihannia orhanizovanii zlochynnosti: teoretychni pytannia [European experience in the prevention of organized crime: Theoretical issues]. Retrieved from: http://referat-ok.com.ua/pravo/ jevropeiskii-dosvid-zapobigannya-organizovanii-zlochinnosti-teoretichni-pitannya (in Ukrainian)

Ruden, V. V. (2014). Perspektyvy ta priorytety rozvytku sotsialno-ekonomichnoi systemy Ukrainy [Perspectives and priorities of the development of the socio-economic system of Ukraine]. Retrieved from: http://intkonf.org/ ruden-vv-perspektivi-taprioriteti-rozvitku-sotsialno-ekonomichnoyi-sistemi-ukrayini/ (in Ukrainian)

Yehorycheva, S. B. (2014). Orhanizatsiia finansovoho monitorynhu v bankakh. Navchalnyi posibnyk [Organization of financial monitoring in banks: a teaching manual]. K.: Tsentr uchbovoi literatury. (in Ukrainian)

Kalman, O.H. (2004). Zlochynnist u sferi ekonomiky Ukrainy: teoretychni ta prykladni problemy poperedzhennia [Crime in the economy of Ukraine: Theoretical and practical problems of prevention] (Dissertation for the degree of Candidate of Juridical Sciences (Ph.D.) in speciality 12.00.08 Criminal Law and Criminology; Criminal and Executive Law). Kharkiv: Yaroslav Mudryi National Law Academy of Ukraine. (in Ukrainian)

Orlov, Yu. Yu. (2006). Poniattia ta elementy orhanizatsii operatyvno-rozshukovoi diialnosti [Concepts and elements of organization of operative and search activity]. Naukovyi visnyk Kyivskoho natsionalnoho universytetu vnutrishnikh sprav, 5, 264-271. (in Ukrainian)

Kharko, D. M. Kryminolohichni problemy shchodo vyznachennia poniattia ta oznak suchasnoi ekonomichnoi zlochynnosti yak faktora tinizatsii ekonomiky Ukrainy [Criminological problems concerning definition of concept and features of modern economic crime as a shadow factor in the Ukrainian economy]. Retrieved from: http://www.apdp.in.ua/v55/119.pdf (in Ukrainian)

Kovalenko, V. V., Moisieiev, Ye. M., Tatsii, V. Ya., Shemshuchenko, Yu. S. (Eds.). (2010). Operatyvno-rozshukova diialnist politsii (militsii) [Operational and search activity of the police (militia)] (Vol. 6). Mizhnarodna politseyska entsyklopediia. In 10 Vols. K.: Atika. (in Ukrainian)

Muntiian, V. I. (1999). Ekonomichna bezpeka Ukrainy [Economic security of Ukraine] (Monography). K.: Publishing House at National Academy of Public Administration under the President of Ukraine. (in Ukrainian) Europe: Hidden economy (June 09, 2011). The Financial Times.

European Security: a common security concept of the 27 WEU. (November 14, 1995). WEU Council of Ministers. Madrid.

Onyshchenko, S. V., Lapinskyi, I. E. (2013). Mizhnarodnyi dosvid borotby z tinizatsiieiu ekonomiky v umovakh hlobalizatsii [International experience in combating the shadow economy in the globalized world]. Efektyvna ekonomika, 2. Retrieved from: http://nbuv.gov.ua/UJRN/efek_2013_2_76 (in Ukrainian)

Sevruk, V. H. (2017). Pravookhoronni orhany, yaki zdiisniuiut protydiiu zlochynam, shcho vchyniaiutsia orhanizovanymy hrupamy i zlochynnymy orhanizatsiiamy, yaki sformovani na etnichniy osnovi: ukrainskyi ta mizhnarodnyi dosvid [Law enforcement bodies countering crimes committed by organized groups and criminal organizations formed on an ethnic basis: Ukrainian and international experience]. Molodyi vchenyi, 11(51), 995-1005. (in Ukrainian)

Shostko, O. (2008). Novi yevropeyski initsiatyvy i pidkhody do protydii OZ [New European initiatives and approaches to countering organized crime]. Visnyk APrN Ukrainy, 2(53), 212-221. (in Ukrainian)

Pchelina, O. V. (2009). Mekhanizm vchynennia ekonomichnykh zlochyniv [Mechanism of committing economic crimes]. Pravo i bezpeka, 4, 118-122. (in Ukrainian)

Dzhuzha, O. M. (2007). Orhanizovana zlochynnist v Ukraini ta krainakh Yevropy: posibnyk [Organized crime in Ukraine and European countries: a teaching manual]. K.: Kyiv National University of Internal Affairs. (in Ukrainian) Pavlenko, S. O. (2013). Deiaki osoblyvosti protydii khabarnytstvu, vchynenomu sluzhbovymy osobamy, yaki zaimaiut vidpovidalne stanovyshche [Some features of counteraction to bribery committed by officials who occupy a responsible position]. Borotba $z$ orhanizovanoiu zlochynnistiu i koruptsiieiu (teoriia i praktyka), 2(30), 279-288. (in Ukrainian)

Kondratenko, M. (February 1, 2018). Suchasnyi stan ekonomichnoi sfery v Ukraini [Modern state of the economic sphere in Ukraine]. Retrieved from: https://uamodna.com/articles/suchasnyy-stan-ekonomichnoyi-sfery-vukrayini/ (in Ukrainian)

Yevropol [Europol]. Retrieved from: https://uk.wikipedia.org/wiki/\%D0\%84\%D0\%B2\%D1\%80\%D0\%BE\% $\mathrm{D} 0 \% \mathrm{BF} \% \mathrm{D} 0 \% \mathrm{BE} \% \mathrm{D} 0 \% \mathrm{BB}$ (in Ukrainian)

Androsovych, L. H. (2018). Orhanizovana zlochynnist u finansovii systemi: suchasnyi etap ta tendentsii [Organized crime in the financial system: the current stage and trends]. Naukovyi visnyk publichnoho ta pryvatnoho prava, 2, 215-224. (in Ukrainian)

Pavlenko, S. O. (2015). Dukhovnist i moralnyi kontrol yak umova zapobihannia ta protydii koruptsii [Spirituality and moral control as a determining factor for the prevention and counteraction of corruption]. Proceedings from scientific and practical conference on legal psychology in Ukraine: achievements and perspectives (Vol. 2). (Kiev, 26 March 2015). V. V. Cherniei, M. V. Kostytskyi, O. I. Kudermina et al. K.: National Academy of Internal Affairs. (in Ukrainian) 